\title{
МАТЕМАТИЧНЕ МОДЕЛЮВАННЯ ПРОЦЕСУ ФРАКЦІОНУВАННЯ ЗЕРНОВОГО МАТЕРІАЛУ У ПНЕВМОГРАВІТАЦІЙНОМУ СЕПАРАТОРІ
}

\author{
Сергій Степаненко ${ }^{1}$, д. т. н., Борис Котов ${ }^{2}$, д. т. н. \\ ${ }^{1}$ Національний науковий центтр «Інститут механізації \\ та електрифікаиії сільського господарства» (ННЦ «ІМЕСГ»), \\ вул. Вокзальна, 11, м. Глеваха, Фастівський р-н, Київська обл., Украӥна, \\ e-mail: Stepanenko_s@ukr.net \\ ${ }^{2}$ Подільський держсавний аграрно-технічний університет (ПДАТУ), \\ вул. Шевченка, 13, м. Кам'янець-Подільський, Хмельниџька обл., Украӥна
}

https://doi.org/10.31734/agroengineering2021.25.012

\begin{abstract}
Степаненко С., Котов Б. Математичне моделювання процесу фракціонування зернового матеріалу у пневмогравітаційному сепараторі

Робота присвячена розробці математичних моделей руху зернівок у складі компонентів зернового матеріалу (КЗМ) в аспіраційному каналі сепаратора. Отримано траєкторії руху зернівок в аспіраційному каналі сепаратора з різними значеннями коефіцієнтів вітрильності (або «парусності»). Отримано рівняння руху зернівки за дії додаткових сил, які дозволяють визначити залежність швидкості руху матеріалу в шарі КЗМ від кутової швидкості обертання зернівки, коефіцієнта вітрильності, геометричних параметрів аспіраційного каналу. Обгрунтовано процес руху зернового матеріалу в аспіраційному каналі сепаратора, що дозволяє визначити раціональні параметри введення КЗМ в аспіраційний канал сепаратора та рівномірного їх розподілу в каналі 3 подальшою можливістю фракціонування. Отримано залежність для функції швидкості потоку зернового матеріалу в аспіраційному каналі сепаратора, що дає змогу визначити параметри розподілу зернового матеріалу за площею перерізу аспіраційного каналу сепаратора. Зроблено оцінку абсолютної швидкості руху зернового матеріалу в аспіраційному каналі сепаратора на основі математичної моделі, побудованої за аналогією з гідродинамічною моделлю, що, своєю чергою, дає змогу проаналізувати рекомбінацію зернівок за товщиною шару зернового матеріалу. За встановленими математичними моделями побудовано графічні залежності абсолютної швидкості руху зернівок від часу, траєкторії руху масиву частинок, розрахункові траєкторії частинок зернового матеріалу, які подаються у пневмоканал за сталих початкових умов. Розроблена математична модель, яка відрізняється від відомих тим, що відтворює дію раніше не врахованих чинників: нерівномірність поля швидкості, дію поперечних сил типу Жуковського і Магнуса, густини зернівок. Аналіз траєкторій зернівок дав змогу в першому наближенні оцінити можливість поділу компонентів зернового матеріалу при низхідному - протитечієвому русі зернівок у вертикальному каналі, а також встановити вплив дії окремих сил і режимів пневмосепарування на величину розгалуження траєкторій, тобто ефективність поділу. Виявлено, що для компенсації або унеможливлення негативного впливу поперечних сил необхідно забезпечити рівномірний повітряний потік у перерізі пневматичного каналу або штучно змінити розподіл швидкості повітря в каналі таким чином, щоб максимальна швидкість повітря в каналі була в пристінковій зоні (на поверхні стінок).
\end{abstract}

Ключові слова: аспіраційний канал, пневмогравітаційний сепаратор, зернівка, змінна швидкість, траєкторія, обертання зернівки, коефіцієнт вітрильності.

\section{Stepanenko S., Kotov B. Mathematical modeling of grain fractionation process in pneumogravity separator}

The work is devoted to development of the mathematical models of grain motion as a part of grain material components (GMC) in the separator's aspiration channel. The trajectories of grain movement in the aspiration channel of the separator with different values of sailability coefficients are obtained. The equation of grain motion under the action of additional forces is obtained, which allows determining dependence of the material velocity in the GMC layer on the angular velocity of the grain, the coefficient of sail (sail), geometric parameters of the aspiration channel. The process of grain material movement in the separator's aspiration channel is substantiated, which allows determining the rational parameters of GMC introduction into the aspiration channel of the separator and its uniform distribution in the channel with the subsequent possibility of its fractionation. The dependence of the function of the grain flow rate in the aspiration channel of the separator is obtained, which allows determining the parameters of distribution of the grain material by the cross-sectional area of the separator aspiration channel. The absolute velocity of grain material in the aspiration channel of the separator is estimated on the basis of a mathematical model built by analogy with the hydrodynamic model, which in its turn allows analyzing the recombination of grains by the thickness of the grain material layer. According to the established mathematical models, the graphical dependences of the absolute velocity of grain on time, the trajectory of the mass of particles, the calculated trajectories of particles of grain material, which are fed into the pneumatic channel under constant initial conditions. A mathematical model has been developed that differs from the known as it reproduces the action of previously unaccounted for factors: the unevenness of the velocity field, the action of transverse forces such as Zhukovsky 
and Magnus, the density of grains. Analysis of the grain trajectories made it possible in the first approximation to estimate the possibility of separation of grain material components in downward - countercurrent grain movement in the vertical channel, as well as to establish the influence of individual forces and pneumatic separation modes on the magnitude of branching trajectories. It was found that to compensate or prevent the negative impact of transverse forces, it is necessary to ensure a uniform air flow in the cross section of the pneumatic channel or artificially change the air velocity distribution in the channel so that the maximum air speed in the channel was in the wall area.

Key words: aspiration channel, pneumatic gravity separator, grain, variable speed, trajectory, grain rotation, sailability coefficient.

Постановка проблеми. Повітряна сепарація (очищення та розділення зернової маси) $\epsilon$ одним із найпоширеніших способів післязбиральної обробки зернових сумішей різних культур $[1 ; 3 ; 5 ; 7 ; 10 ; 11 ; 13 ; 16]$. Для реалізації повітряної сепарації використовують пневмосепаратори, які характеризуються простотою конструкції i компактністю, а також надійні в експлуатації. Існуючі конструкції пневмосепаруючих робочих органів розділяють зернові суміші за аеродинамічними властивостями зернівок тільки на дві основні фракції: важку та легку [9]. Тому їх використовують для очищення зерна від дрібних домішок або для повторного розділення за розміром чи за густиною: при введенні матеріалу у потік повітря зернівки однакової густини розділяються за розміром або розподіляються за густиною. При цьому існує стійкий зв'язок між критичною швидкістю та їхніми біологічними властивостями. Насіння, що має високу критичну швидкість, має кращі біологічні властивості. Тому доцільно використовувати повітряний потік для розділення насіннєвого матеріалу на декілька фракцій. Поява нових конструкцій пневмосепараторів 3 нижньою зоною розділення і вивантаження окремих фракцій дає змогу використовувати спосіб розділення за траєкторіями в пневмогравітаційних каналах зерноочисних машин, що $є$ перспективним напрямом їх удосконалення.

Незважаючи на широке використання повітряних потоків у машинах для сепарації зернового матеріалу, можливості його поділу за аеродинамічними властивостями використовуються вкрай не достатньо, особливо в найпоширеніших пневмогравітаційних сепараторах машинах із вертикальним повітряним каналом.

Основною причиною цього $є$ недостатня вивченість процесів взаємодії компонентів зернового матеріалу (КЗМ) з повітряним потоком у каналах із жорсткими стінками. Постійне вдосконалення конструкції повітряних зерносепаруючих машин i агрегатів із метою інтенсифікації режимів їхньої роботи й поліпшення якості функціонування потребує більш глибокого вивчення закономірностей перебігу процесів переміщення частинок КЗМ у каналах пневмогравітаційних сепараторів.

Для виявлення та оцінки способів підвищення ефективності поділу КЗМ за аеродинамічними властивостями, які найщільніше корелюють із біологічними особливостями зерна, необхідно мати більш точний опис силової взаємодії частинок зернового матеріалу 3 повітряними потоками, які під час руху в каналах мають нерівномірний розподіл швидкості повітря в поперечному перерізі каналу.

Аналіз останніх досліджень і публікацій. Огляд існуючих технологій і технічних засобів для сепарації зернового матеріалу повітряним потоком та аналіз результатів їх досліджень дав змогу виявити таке. Вертикальні пневмосепаратори, які використовуються на зернопереробних підприємствах, як правило, сепарують матеріал як двофракційну суміш, за різницею опору повітряному середовищу різних фракцій зернового матеріалу. Для поділу зернової суміші на декілька фракцій у повітряному потоці використовують похилі пневмоканали й принципи пневмоінерційної сепарації за допомогою вкидання зернової маси у всмоктувальний чи нагнітальний повітряний потік. Розділення відбувається за рахунок різниці в опорі повітрю компонентів зернової суміші (маси), яка подається в аспіраційний канал із досить великою початковою швидкістю. Встановлено, що найбільш впливовими на технологічну ефективність сепарації [14] чинниками є: аеродинамічні властивості [4] матеріалу і питоме навантаження на пневмоканал; характеристики повітряного потоку і геометрія каналу; умови введення зернової суміші в повітряний потік.

Враховуючи всі складнощі процесів і впливових чинників для визначення раціональних параметрів пневмогравітаційного сепаратора 3 нижньою зоною вивантаження поділених фракцій необхідно дослідити процес переміщення КЗМ. Для дослідження процесу переміщення зернівок під дією силової взаємодії 3 повітряним потоком необхідно сформулювати математичний опис, який допоможе отримати траєкторії руху частинок у повітряному каналі з градієнтом швидкості повітря. 
Аналіз існуючих математичних моделей, які використовують для опису переміщення частинок у середовищах з опором, показує, що в більшості досліджень використовують диференціальні рівняння П. М. Василенка [4], які враховують тільки дві сили: опору i тяжіння. Водночас у роботі [6] досить детально визначено наявність бокових сил, а в роботі [2] враховано понад сім сил, які діють на частинку. У працях [8; 17-19] наведено моделі, які враховують різні (альтернативні) сили, що описують повну фізичну картину взаємодії частинок із нерівномірним повітряним потоком.

Врахувати всі сили доволі складно, тому потрібний теоретичний аналіз для формування математичного опису i визначення траєкторій переміщення частинок.

Постановка завдання. Наше завдання аналіз силової взаємодії частинок матеріалу 3 повітряним потоком i формулювання вдосконаленої математичної моделі для визначення траєкторій руху компонентів зернового матеріалу.

Виклад основного матеріалу. Загальну кількість сил і моментів, що діють на частинку в повітряному потоці (як правило, це дифузійні, електростатичні, термодинамічні та інші), на сьогодні не визначено, оскільки немає опису явищ, які визначають поведінку частинки в повітряному рухомому середовищі.
Тому математичний опис руху частинки можна скласти тільки для найпростіших або спрощених умов (випадків). До таких умов належать такі вихідні припущення, які використовують у більшості робіт, присвячених процесам переміщення моно- і полідисперсного матеріалу під дією повітряного потоку:

1) несучий потік є однорідним нестисливим середовищем із нормованими параметрами (тиск, температура, густина);

2) в'язкі сили між повітряним потоком i стінами каналу, а також внутрішнє тертя відсутні;

3) рух потоку - стаціонарний;

4) частинки мають сферичну форму i між собою та стінками каналу не взаємодіють;

5) електричні i термодифузійні сили не враховуються.

Розглянемо несучий повітряний потік, обмежений стінками каналу (швидкість повітря в площині, нормальній до напрямку його руху, розподілена $\left.-v_{\text {п }}(x, y)\right)$. Рух зернівки відбувається в площині в декартовій прямокутній системі координат $X O Y$. Приймемо, що канал розміщений вертикально, як у найпоширеніших схемах пневмосепараторів. Рух повітря приймемо висхідний, а рух зернинок - низхідний, тобто завантаження аспіраційного каналу відбувається зверху.

Сили, що діють на частинку, розглядаємо відповідно до схеми (рис. 1).

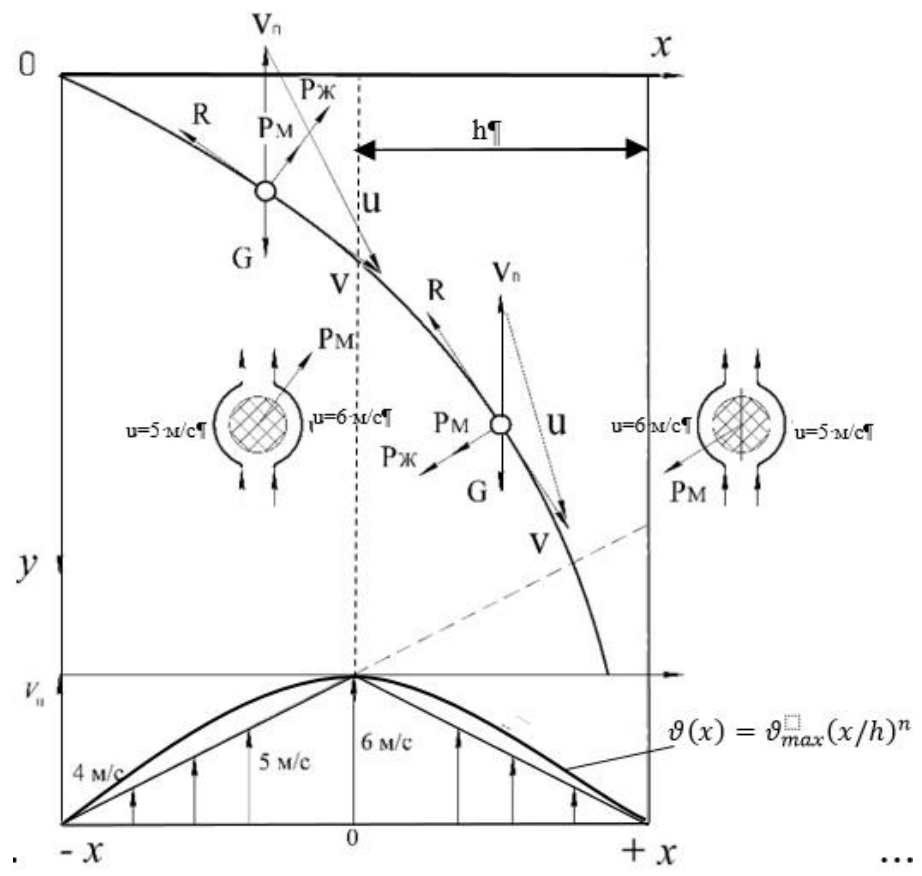

Рис. 1. Схема силової взаємодії зернівки з нерівномірним повітряним потоком

Fig. 1. Scheme of force interaction of grain with uneven air flow 
Для формулювання математичної моделі динаміки руху частинки у вертикальному каналі й уточнення механізму дії розглянутих сил

$$
\begin{gathered}
m \frac{d \bar{v}}{d \tau}=\bar{R}+\bar{F}_{1}+\bar{F}_{2}+ \\
J \frac{d \omega}{d t}=M
\end{gathered}
$$

На сьогодні відсутня точна теорія, яка б дала змогу визначити дійсну силу аеродинамічного опору $R$, тому використовуватимемо квадратичну залежність від швидкості обтікання частинки:

$$
R=0,5 \xi R_{e} \rho_{\Pi} S_{\mathrm{M}} v_{\Pi}-v_{\mathrm{u}} \quad \vartheta_{\Pi}-\vartheta_{\mathrm{u}}, \quad 2
$$

де $\xi R_{e}$ - коефіцієнт опору, що $\epsilon$ функцією числа Рейнольдса; $\rho_{\text {п }}$ - густина повітря; $S_{\mathrm{M}}=$ $\frac{\pi d_{e}^{2}}{4}$ - площа міделевого перерізу зернівки; $d_{e}-$ еквівалентий діаметр $\left(d_{e}={ }^{3} \frac{\overline{6 V_{\mathrm{u}}}}{\pi}\right) ; \quad V_{\mathrm{\Psi}}-$ об'єм частинки; $v_{\text {п }}$-швидкість повітряного потоку; $v_{\mathrm{ч}}-$ швидкість зернівки.

Оскільки значення коефіцієнта аеродинамічного опору зернівки $\xi R_{e}$ залежить від форми, режиму обтікання повітряним потоком $f R_{e}$, iï орієнтації в повітряному потоці, у подальших розрахунках використовуватимемо (для визначення значення аеродинамічного опору) коефіцієнт $K_{V}$ вітрильності (або «парусності»), який визначається зі співвідношення

$$
k_{V}=\frac{\xi R_{e} \cdot S_{\mathrm{M}} \cdot \rho_{3}}{m}=\frac{g}{V_{\text {Вит }}^{2}},
$$

де $m$-маса зернівки; $V_{\text {вит }}$ - швидкість витання зернівки; $\rho_{3}$ - густина зернівки; $g$ - прискорення вільного падіння.

Коефіцієнт вітрильності визначається фізико-механічними властивостями зернівки, коефіцієнтом аеродинамічного опору, який залежить від режиму повітряного потоку в каналі і форми зернівки. Під час експериментального визначення швидкості витання (певного класу зернівок) розраховані значення $k_{V}=g / V_{\text {вит }}^{2}$ враховуватимуть форму зернівки та її орієнтацію.

Таким чином, сила аеродинамічного опору зернівки визначатиметься спрощеним виразом:

$$
R=k_{V} \cdot U^{2} \cdot m=k_{V} V_{\Pi}-V^{2} \cdot m, \quad 4
$$

де $U$-відносна швидкість зернівки в повітряному потоці.

Зміна в часі швидкості зернівки призводить до виникнення сили інерції зернівки 3 масою $m$, вектор якої спрямовано протилежно вектору швидкості переміщення: скористаємося моделлю силової взаємодії зернівки з нерівномірним потоком, наведеною на рис. 1, тоді:

$$
F_{1}=m \frac{d v}{d t} .
$$

Зміна в часі швидкості потоку повітря зумовлює появу сили інерції:

$$
F_{2}=m \frac{d v_{\Pi}}{d t} .
$$

Вектор сили інерції спрямовано нормально до траєкторії потоку, що проходить через центр тяжіння частинки.

Сила тяжіння спрямована в напрямку прискорення вільного падіння:

$$
G=m g \text {. }
$$

Виштовхувальна сила (Архімеда) спрямована протилежно силі тяжіння:

$$
F_{a}=V_{\text {ч }} \rho_{\text {п }} g .
$$

Зусилля, що зумовлено зміною тиску в напрямку переміщення несучого потоку за рахунок його прискорення:

$$
F_{\mathrm{p}}=V_{\mathrm{u}} \rho_{\mathrm{\Pi}} \frac{d V_{\Pi}}{d t} .
$$

Як результат нерівномірного розподілу швидкості повітряного потоку зернівка може отримати обертальний рух навколо своєї осі; за таких умов виникає сила типу Магнуса, яка діє в напрямку, нормальному до вектора відносної швидкості зернівки, та в бік збільшення швидкості повітря в поперечному перерізі каналу $v_{\text {п }} x$ :

$$
P_{\mathrm{M}}=S_{r} U \Gamma_{\mathrm{M}},
$$

де $\Gamma_{\mathrm{M}}$ - циркуляція швидкості повітря при обертанні циліндра, еквівалентного кулі, визначається за формулою

$$
\Gamma_{\mathrm{M}}=2 \pi r_{e} U=\frac{8}{3} \pi r_{e}^{3} \omega,
$$

де $\omega$ - кутова швидкість обертання зернівки.

$$
P_{\mathrm{M}}=\frac{8}{3} \pi S_{\mathrm{M}}{\frac{d_{e}}{2}}^{3} \omega v_{\text {п }} x \bar{i}-U,
$$

де $v_{\text {п }} x$-розподіл швидкості потоку повітря в поперечному перерізі каналу; $\bar{i}$ - одиничний вектор осі $y ; d_{e}-$ еквівалентний діаметр зернівки, $\left(d_{e}=2 r_{e}\right) ; r_{e}$ - радіус зернівки.

Наявність градієнта швидкості повітряного потоку i, відповідно, градієнта відносної швидкості $\operatorname{qrad} U$ зумовлюе виникнення другої «бокової» сили типу М. Жуковського:

$$
P_{\text {ж }}=S U \Gamma_{2},
$$


де $\Gamma_{2}=U d l-$ циркуляція швидкісного поля повітряного потоку:

$$
\Gamma_{2}=\pi r_{y}^{2} \operatorname{qrad} U_{y}=\pi r_{y}^{2} \frac{d U}{d x} .
$$

Приймаючи, у першому наближенні, найпоширеніший степеневий закон розподілу швидкості повітря за перерізом каналу [15]:

$$
v_{\text {п }} x=v_{\max } \frac{x}{h}^{n} \bar{i}
$$

де $h$ - відстань від осі каналу до стінок; $v_{\max }-$ швидкість повітряного потоку на осі каналу; $x-$ координата зернівки в деякий момент часу $\mathrm{t} ; n-$ показник степеня, який залежить від критерію Рейнольдса,

визначимо відносну швидкість зернівки

$$
\bar{U}=v_{\max } \frac{x}{h}^{n} \bar{i}-\bar{v}_{\Pi}
$$

і її градієнт

$$
\frac{d U}{d x}=\frac{v_{\max } \cdot n}{h^{n}} x^{n-1}
$$

Тоді силу Жуковського запишемо у такому вигляді:

$$
\begin{aligned}
& P_{\text {Ж }}=\frac{v_{\max } \cdot n \cdot x^{n-1}}{h^{n}} \\
& v_{\max } \frac{x^{n}}{{ }^{n}}{ }^{n}-\bar{v}_{\Pi} \pi r_{e}^{2} \cdot \rho_{3} .
\end{aligned}
$$

Якщо відома початкова кутова швидкість обертання частинки у вигляді кулі $-\omega_{0}$, то змінну (поточну) величину $\omega t$ можна визначити з рівняння [13;14]:

$$
\begin{aligned}
\omega t & =\omega_{0} e^{-k_{\omega} t}, \\
k_{\omega} & =\frac{18 \mu}{\rho_{3} r_{e}{ }^{2}},
\end{aligned}
$$

де $\mu$ - динамічний коефіцієнт в'язкості повітря; $\rho_{3}$ - густина зернівки; $\omega_{0}$ - початкова кутова швидкість обертання зернівки; $t$ - час перебування зернівки в повітряному потоці.

До сил, які не враховані в рівнянні (1), належать сили аеродинамічної взаємодії між частинками при зіштовхуванні, електричні сили внаслідок тертя, сила термофорезу, яка виникає під час руху в потоці 3 нерівномірною температурою, але через незначний вплив наведених сил порівняно із силами, що входять до системи рівнянь (1), ними можна знехтувати.

3 кількісного аналізу сил, що увійшли до рівняння (1) при реальних (робочих) параметрах твердої і газової фаз, можна не брати до уваги сили $F_{2}, F_{a}$ і $F_{p}$, оскільки їхні значення набагато менші від сил $G$ і $R$.

Для кінцевого формулювання математичної моделі динаміки руху зернівок у вертикальному каналі пневмогравітаційного сепаратора зробимо ще декілька припущень:

- зернівки є твердими частинками сферичної форми, які відрізняються масою і розміром;

- за ознаку поділу прийнято коефіцієнт вітрильності $k_{V}$;

- повітряний потік стаціонарний, швидкість якого розподілена в поперечному перерізі за степеневим законом $v(x)=v_{\max } \frac{x}{h}^{n}$ або за логарифмічним $v x=v_{\max } 1-k \ln \frac{h}{x}$;

- зернівки між собою $\mathrm{i}$ стінкою не взаємодіють.

Основним рівнянням руху зернівки в повітряному потоці $є$ рівняння руху іiі центра маси у вигляді

$$
m \frac{d \bar{v}}{d t}=\bar{R}+\bar{G}+\bar{P}_{ж}+\bar{P}_{\mathrm{M}}
$$

і за наявності обертального руху

$$
J \frac{d \omega}{d t}=M ; \quad \omega=\frac{d \varphi}{d t} ; \quad \frac{d r}{d t}=\bar{v} .
$$

Спроєктувавши вектори обох частин рівняння (20) на нерухомі прямокутні осі (системи координат $X 0 Y) 0 x$ і $0 y$, отримаємо систему диференціальних рівнянь, що описують динаміку руху зернівки у вертикальному повітряному потоці.

Ураховуючи турбулентний рух повітряного потоку у вертикальному пневмоканалі, для опису розподілу швидкості повітря в перерізі пневмоканалу прийнято логарифмічний закон розподілу за формулою А. Альтшуля:

$$
\frac{\vartheta(x)}{\vartheta_{\max }}=1-k_{\lambda} \cdot \ln \frac{h}{x t+r_{\mathrm{U}}},
$$

де $k_{\lambda}=0,87 \frac{0,975}{\bar{\lambda}}+1,35^{-1} ; \lambda$ - коефіцієнт опору повітря в трубопроводі; $h$ - відстань від зовнішньої поверхні каналу до центра; $r_{\text {ц }}$ - радіус еквівалентного циліндра.

При логарифмічному розподілі швидкості повітряного потоку (22) [12; 15] рівняння (20) у координатній формі (для площинного руху в координатах ХОУ) набуває такого вигляду:

$$
\begin{aligned}
& \frac{d^{2} x t}{d t^{2}}=-k_{V} \frac{d x t}{d t} \overline{\frac{d x t^{2}}{d t}+\frac{d y t}{d t}+\vartheta x^{2}}+\mathrm{P}_{\text {X } x}+\mathrm{P}_{\mathrm{M} x} m^{-1} \frac{\frac{d x t}{d t}}{{\frac{d x t}{d t}{ }^{2}+\frac{d y t}{d t}+\vartheta x}^{2}},
\end{aligned}
$$

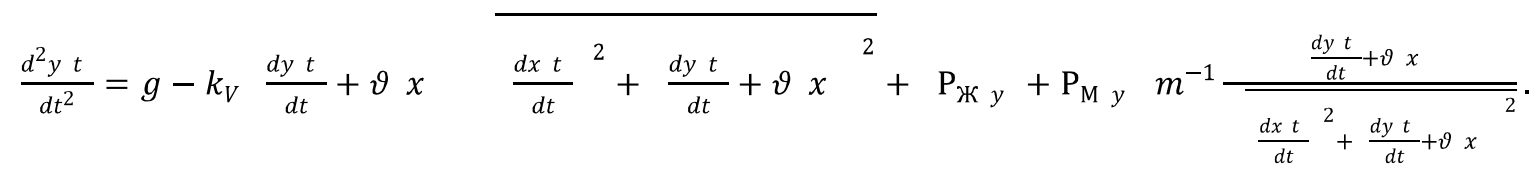


Проєкції сил:

$$
\begin{aligned}
& \mathrm{P}_{\text {Ж } x}=\frac{4}{3} \pi r_{\mathrm{L}}^{3} \rho \frac{d x}{d t} \vartheta_{\max }^{*} \frac{k_{V}}{x t+r_{\mathrm{L}}}, \\
& \mathrm{P}_{M x}=\frac{8}{3} \pi r_{\mathrm{L}}^{3} \rho \omega(t) \frac{d x}{d t}, \\
& \mathrm{P}_{\text {Ж } y}=\frac{4}{3} \pi r_{\mathrm{L}}^{3} \rho \vartheta_{\max }^{*} 1-k_{V} \cdot \ln \frac{h}{x t+r_{\mathrm{U}}}+\frac{d y}{d t} \vartheta_{\max }^{*} \frac{k_{V}}{x t+r_{\mathrm{UL}}}, \\
& \mathrm{P}_{M y}=\frac{8}{3} \pi r_{\mathrm{L}}^{3} \rho \omega(t) \frac{d y}{d t}+\vartheta_{\max }^{*} 1-k_{V} \cdot \ln \frac{h}{x t+r_{\mathrm{U}}} \\
& \vartheta(x)=\vartheta_{\max }^{*} 1-k_{V} \cdot \ln \frac{h}{x t+r_{u}},
\end{aligned}
$$

Початкові умови:

$$
\begin{gathered}
x_{t=0}=-x+r_{\mathrm{L}} ; \\
x 0=0 ; y 0=0 ; \\
x 0=\frac{d x}{d t}{ }_{t=0}=\vartheta_{o} \cos \theta_{0} ; \\
y 0=\frac{d y}{d t}(t=0)=\vartheta_{o} \sin \theta_{0},
\end{gathered}
$$

де $\vartheta_{o}, \theta_{0}$ - початкова швидкість і кут подачі матеріалу в канал.

Граничні умови:

$$
x<0 ; \mathrm{P}_{Ж}>0 ; \mathrm{P}_{M}>0 ; x>0 ;
$$

$\mathrm{P}_{\text {Ж }}<0 ; \mathrm{P}_{M}<0 ;-x-r_{\text {ᄂ }} \leq x \leq x-r_{\text {Ц }}$.

Обертання частинки відбувається зі змінною в часі кутовою швидкістю $\omega t$, iї значення визначається 3 диференціального рівняння обертання кулі у в'язкому середовищі:

$$
\frac{d \omega(t)}{d t}=-15 \frac{\mu \omega}{\rho_{3} r_{e}^{2}}
$$

Завдяки заміні для спрощення розрахунків рівняння (22) степеневим розподілом

$$
\vartheta(x)=\vartheta_{\max }{\frac{x t+r_{\text {แ }}}{h}}^{0,1},
$$

визначено зміну частоти обертання частинки диференціальним рівнянням вигляду

$$
\begin{aligned}
I \frac{d \omega}{d t}= & 0,454 \cdot \frac{h-x t \cdot r_{\mathrm{L}}}{h-r_{\mathrm{L}}} \cdot k_{V} \cdot \\
& \cdot \vartheta_{\max } \frac{x t}{h}^{0,1}-\frac{d x t}{d t} .
\end{aligned}
$$

Ураховуючи, що у двофазному протитечієвому потоці певної концентрації зменшується площа вільного перерізу для руху повітря, відповідно збільшується швидкість обтікання частинки. Швидкість руху повітря в міжзерновому просторі можна враховувати через порозність двофазного шару $-\varepsilon$ за очевидною формулою:

$$
V_{\Pi}=v_{f} / \varepsilon,
$$

де $v_{f}$ - швидкість повітря в каналі без матеріалу.

Тоді максимальну швидкість матеріалу визначатимемо таким чином:

$$
v_{\max }{ }^{*}=\frac{v_{\max }}{\varepsilon} ; \varepsilon=\frac{1}{1+\chi} ;
$$

$$
\chi=\frac{v_{t} \cdot \rho_{t}}{V_{\Pi} \cdot \rho_{\Pi}} ; v_{\max }^{*}=v_{\max } \cdot 1+\chi,
$$

де $\chi$ - концентрація зернового матеріалу в аспіраційному каналі.

Удосконалена математична модель (23) відрізняється від відомих тим, що відтворює дію раніше не врахованих чинників (нерівномірність поля швидкості, дію поперечних сил типу Жуковського і Магнуса, густини зернівок). Розв'язок вихідних рівнянь 3 початковими умовами виконаний у програмному середовищі MathCad i наведений на рис. 2 та 3.

Аналіз траєкторій зернівок (див. рис. 2, 3) дав змогу в першому наближенні оцінити можливість поділу компонентів при низхідному-протитечієвому русі зернівок у вертикальному каналі, а також встановити вплив дії окремих сил $\mathrm{i}$ режиму сепарування на величину розгалуження траєкторій (ця величина визначає ефективність поділу). При забезпеченні рівномірного поля швидкостей ефективність поділу в низхідному русі зернівок підвищується (рис. 4,5 ).

Аналіз траєкторій показує, що дія поперечних сил, викликана нерівномірною епюрою швидкості повітря, негативно впливає на величину розгалуження траєкторій, оскільки зменшується ефективність розсіювання траєкторій, тобто відстань між траєкторіями звужується.

Степеневий, або логарифмічний, закон природного розподілу швидкості повітря в каналах призводить до виникнення градієнта швидкості потоку, дії додаткових бокових сил (нормальних до вектора відносної швидкості зернівки), що зумовлює зменшення ефекту «розсіювання» зернівок і розщеплення траєкторій. У вертикальному каналі це звуження траєкторій до осі симетрії кривої розподілу, а для горизонтального каналу (незалежно від напряму введення в потік) траєкторії звужуються в струмінь і мають більш крутий нахил, що вказує на зменшення часу перебування зернівки в пневмоканалі (скорочення лінії траєкторії). 


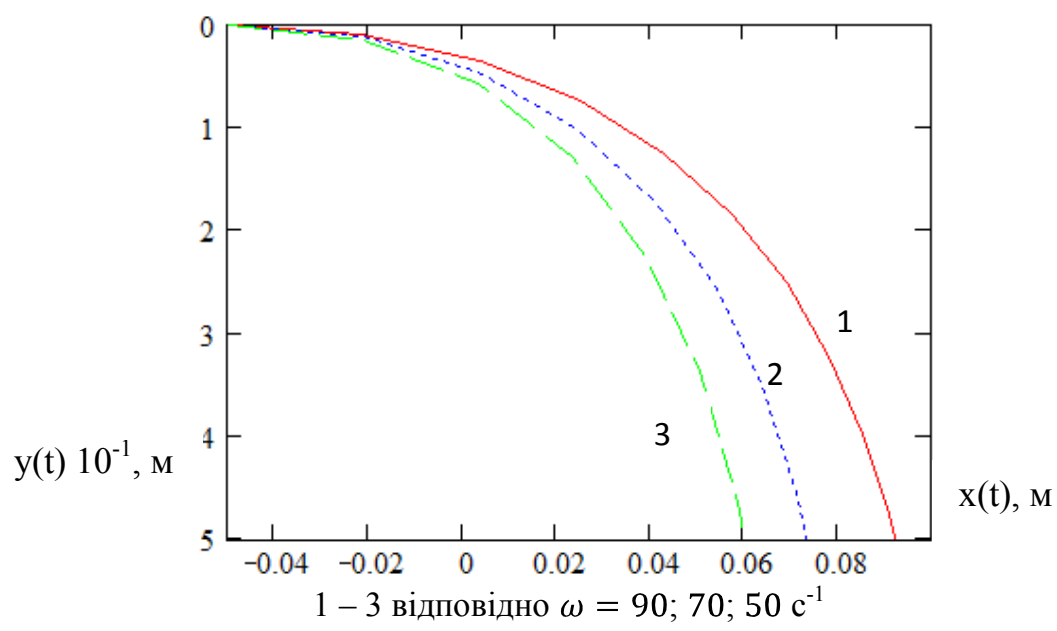

Рис. 2. Траєкторії руху зернівок у пневмосепаруючому вертикальному каналі

Fig. 2. Trajectories of grain move in the pneumatic separating vertical channel

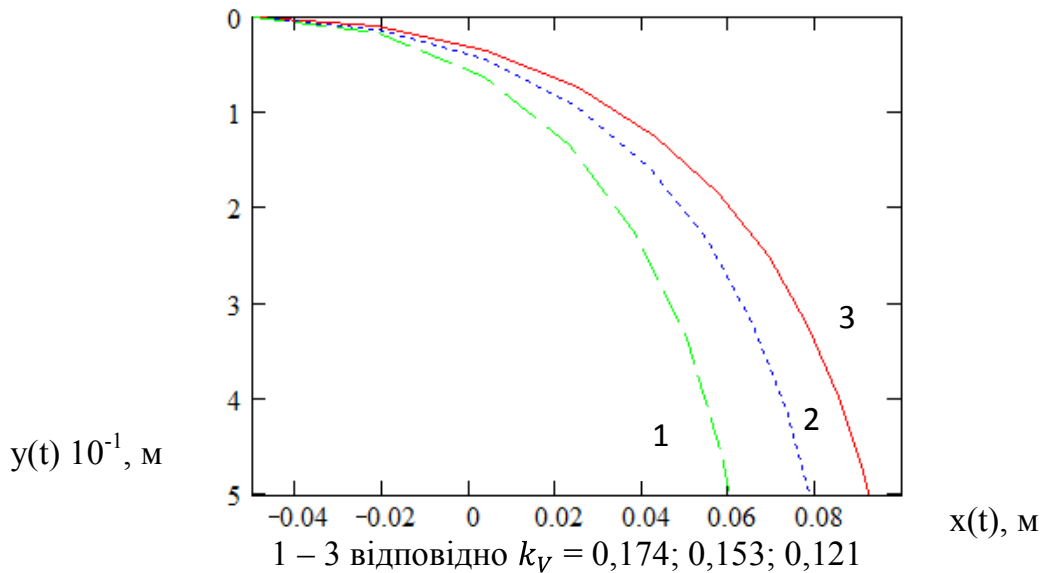

Рис. 3. Траєкторії руху зернівок у пневмосепаруючому вертикальному каналі

Fig. 3.Trajectories of grain move in the pneumatic separating vertical channel

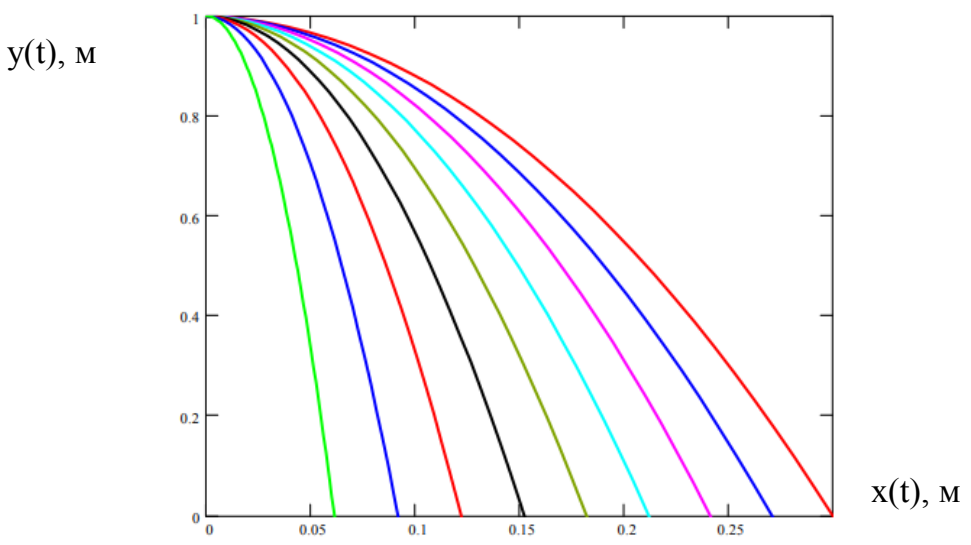

Рис. 4. Розрахункові траєкторії зернового матеріалу, який подається

в пневмоканал, за початкових умов: швидкість повітряного потоку 6 м/с, кут введення $9^{\circ}$, початкова швидкість від 0,1 до $0,5 \mathrm{~m} / \mathrm{c} 3$ кроком $0,05 \mathrm{M} / \mathrm{c}$ при рівномірному повітряному потоці Fig. 4. Estimated trajectories of grain material fed into the pneumatic channel under initial conditions: air flow rate $6 \mathrm{~m} / \mathrm{s}$, input angle $9^{\circ}$, initial speed from 0.1 to $0.5 \mathrm{~m} / \mathrm{s}$ with a step of $0.05 \mathrm{~m} / \mathrm{s}$ at uniform air flow 


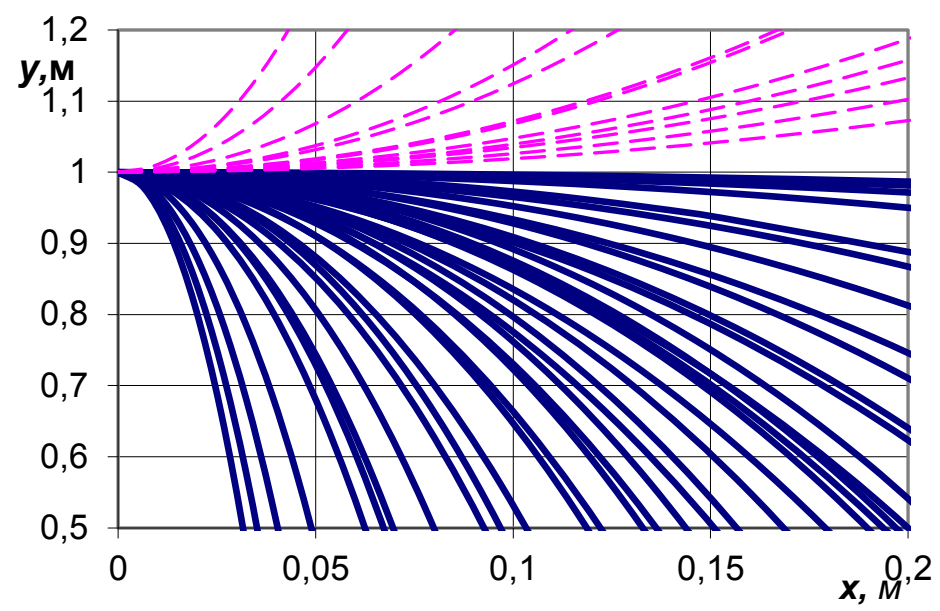

Рис. 5. Траєкторії руху масиву зернівок за початкових швидкостей введення $0,1-0,6 \mathrm{~m} / \mathrm{c}$

Fig. 5. Trajectories of grain move at the initial velocities of $0.1-0.6 \mathrm{~m} / \mathrm{s}$

\section{Висновки}

1. Розроблена математична модель, яка відрізняється від відомих тим, що відтворює дію раніше не врахованих чинників (нерівномірність поля швидкості, дію поперечних сил типу Жуковського і Магнуса, густини зернівок).

2. Аналіз траєкторій зернівок дав змогу в першому наближенні оцінити можливість поділу компонентів зернового матеріалу при низхідному - протитечієвому русі зернівок у вертикальному каналі, а також встановити вплив дії окремих сил і режиму пневмосепарування на величину розгалуження траєкторій (ця величина визначає ефективність поділу).

3. Виявлено, що для компенсації або унеможливлення негативного впливу поперечних сил необхідно забезпечити рівномірний повітряний потік у перерізі каналу або штучно змінити розподіл швидкості повітря в каналі таким чином, щоб максимальна швидкість повітря в каналі була в пристінковій зоні (на поверхні стінок).

\section{Бібліографічний список}

1. Абдуєв М. М. Обгрунтування параметрів сепаратора з нахиленим повітряним каналом для розділення зернових сумішей: автореф. дис. ... канд. техн. наук. Харків, 2007. 20 с.

2. Алієв Е. Б. Механіко-технологічні основи процесу прецизійної сепарації насіннєвого матеріалу соняшника: автореф. дис. ... д-ра техн. наук. Харків, $2020.40 \mathrm{c}$.

3. Борщ Ю. П. Моделирование динамики расслоенной зерновой смеси в вертикальном канале пневмосепарирующих устройств зерновых сепараторов. Вісник Харківського начіонального технічного університету сільського господарства імені Петра Василенка. 2014. Вип. 152. С. $128-135$.
4. Василенко П. М. Теория движения частицы по шероховатым поверхностям сельскохозяйственных машин. Киев: УАСХН,1960. 252 с.

5. Єрмак В. П. Концепція аеродинамічної сепарації насіння сільськогосподарських культур та засоби іiі реалізації: автореф. дис. ... д-ра техн. наук. Тернопіль, 2009. $39 \mathrm{c}$.

6. Зуєв Ф. Г. Пневматическое транспортирование на зерноперерабатывающих предприятиях. Москва: Колос, 1979. 344 с.

7. Колодій О. С. Обгрунтування конструктивнотехнологічних параметрів пневмогравітаційного сепаратора насіння соняшника: автореф. дис. ... канд. техн. наук. Мелітополь, 2015. 23 с.

8. Котов Б. І., Степаненко С. П. Дослідження впливу пульсуючого повітряного потоку на переміщення зерна у віброзрідженому шарі зерносоломистого вороху. Механізація та електрифікація сільського господарства: міжвідом. темат. наук. зб. Глеваха, 2016. Вип. № 4 (103). С. 38-46.

9. Кюрчев С. В. Механіко-технологічне обгрунтування післязбиральної обробки та зберігання насіння зернових і олійних культур: автореф. дис. ... д-ра техн. наук. Глеваха, 2019. 44 с.

10. Моделювання технологічних процесів в типових об'єктах післязбиральної обробки і зберігання зерна (сепарація, сушіння, активне вентилювання, охолодження): монографія / Б. І. Котов та ін. Ніжин: ПП Лисенко М. М., 2017. 552 с.

11. Нестеренко О. В. Обгрунтування параметрів пневмосепаруючого каналу з багаторівневим введенням зернового матеріалу: автореф. дис. ... канд. техн. наук. Кропивницький, 2017. 21 с.

12. Ольшанский В. П., Ольшанский С. В. О траектории полета вращающейся сферической частицы. Вісник Харківського національного технічного університету сільського господарства імені Петра Василенка. 2009. Вип. 88. С. 54-61.

13. Степаненко С. П. Механіко-технологічне обгрунтування процесів і обладнання безрешітного 
фракціонування зернових матеріалів: автореф. дис. ... д-ра техн. наук. Глеваха, 2021. 50 с.

14. Степаненко С. П., Котов Б. І. Дослідження закономірностей руху компонентів зернового матеріалу під час пневмогравітаційного фракціонування у вертикальному каналі. Механізація та електрифікація сільського господарства: загальнодерж. зб. Глеваха, 2018. Вип. № 7 (106). С. 82-89.

15. Степанов Г. Ю., Зицер И. М. Инерционные воздухоочистители. Москва: Машиностроение, 1986.184 с.

16. Швидя В. О. Підвищення ефективності пневмовідцентрового сепаратора та обгрунтування параметрів робочих органів: автореф. дис. ... канд. техн. наук. Глеваха, 2012. 20 с.
17. Stepanenko S. P., Kotov B. I. Pneumonitis fractionation of grain materials in air streams of variable structure. Machinery \& Energetics. Journal of Rural Production Research. 2020. Vol. 11, No. 1. P. 127-132. doi: 10.31548/machenergy.2020.01.127-132.

18. Stepanenko S. P., Kotov B. I. Theoretical research of separation process grain mixtures. TEKA. An International Quarterly Journal on Motorization, Vehicle Operation, Energy Efficiency and Mechanical Engineering. 2018. Vol. 18, No. 3. P. 49-54.

19. Theory of motion of grain mixture particle in the process of aspiration separation / V. Bulgakov et al. Agronomy Research. 2020. 18(S2). P. 1177-1188. doi: 10.15159/AR.20.069.

Стаття надійшла 27.06.2021 